\title{
Effects of inhaled furosemide on platelet-activating factor challenge in mild asthma
}

\author{
A.L. Echazarreta*, F.P. Gómez*, J. Ribas*, M. Achaval*, J.A. Barberà*, J. Roca*, \\ K.F. Chung ${ }^{+}$, R. Rodriguez-Roisin*
}

Effects of inhaled furosemide on platelet-activating factor challenge in mild asthma. A.L. Echazarreta, F.P Gómez, J. Ribas, M. Achaval, J.A. Barberà, J. Roca, K.F. Chung, R. Rodriguez-Roisin. (C) ERS Journals Ltd 1999.

ABSTRACT: Furosemide (Fur) may have an anti-inflammatory effect on airways in patients with asthma although its intrinsic mechanism remains elusive. Plateletactivating factor (PAF) is a potent proinflammatory mediator that induces systemic and respiratory effects in normal control subjects and asthmatics. The aim of this study was to assess whether pretreatment with nebulized Fur $(40 \mathrm{mg})$ was able to modulate PAF-induced systemic and respiratory effects in asthma.

Eleven patients were studied (mean \pm sem $22 \pm 0.8$ yrs) with mild asthma (forced expiratory volume in one second, $95 \pm 4 \%$ ) in a randomized, double-blind, placebocontrolled, cross-over fashion, one week apart. PAF challenge $(18 \mu \mathrm{g})$ was carried out 15 min after administration of Fur or placebo. Peripheral blood neutrophils, respiratory system resistance, and arterial blood gases were measured at baseline, and 5, 15 and $45 \mathrm{~min}$ after PAF; urinary cysteinyl leukotriene $\mathbf{E}_{4}\left(\mathrm{ULTE}_{4}\right)$ was also measured, at baseline and $120 \mathrm{~min}$ after PAF challenge.

Although Fur did not alter PAF-induced systemic and respiratory effects, it did partially inhibit $(63 \% ; p<0.04)$ the increments of $\mathrm{uLTE}_{4}$ levels shown after PAF inhalation.

It is concluded that furosemide is not effective in protecting against plateletactivating factor challenge in patients with asthma despite its potential inhibition of leukotriene synthesis. These findings reinforce the view that the pulmonary effects of platelet-activating factor are mediated through different pathways.

Eur Respir J 1999; 14: 616-621.
*Servei de Pneumologia i Al.lèrgia Respiratòria, Dept de Medicina, Institut d'Investigacions Biomédiques August $\mathrm{Pi}$ i Sunyer (IDIBAPS), Hospital Clínic, Universitat de Barcelona, Barcelona, Spain. ${ }^{+}$National Heart \& Lung Institute, Imperial College School of Medicine, London, UK.

Correspondence: R. Rodriguez-Roisin, Servei de Pneumologia i Al.lérgia Respiratòria, Hospital Clínic, Villarroel 170, 08036-Barcelon,a Spain.

Fax: 34932275404

Keywords: Airway obstruction

bronchoconstriction

diuretics

inflammatory mediators

leukotrienes

pulmonary gas exchange

Received: November 241998

Accepted after revision April 191999

Supported by Grants $97 / 0143$ from the Fondo de Investigación Sanitario (FIS), the Comissionat per a Universitats i Recerca de la Generalitat de Catalunya (1997 SGR00086), and an educational grant from ASTRA-España (1998). AL Echazarreta was supported by a Predoctoral Research Fellowship from the European Respiratory Society (ERS) (1997), FP Gómez by a Predoctoral Research Fellowship from the ERS (1996), and M Achaval by GlaxoWellcome, Argentina.
Platelet-activating factor (PAF) provokes, in both normal individuals and patients with asthma, neutropenia, bronchoconstriction, increased mucus secretion and microvascular leakage in the airways. In addition, PAF induces a ventilation-perfusion $\left(V^{\prime} \mathrm{A} / Q^{\prime}\right)$ imbalance which leads to gas exchange disturbances predominantly related to altered airway vascular permeability [1].

Several studies have demonstrated that inhaled furosemide (Fur) pretreatment reduces the severity of the asthmatic response to different types of constrictor stimuli, more specifically, those which act through indirect bron-choconstrictor mechanism. Likewise, it has been suggested that Fur may have an anti-inflammatory effect through inhibiting mediator release from various cell types [2]. However, its precise mechanism of action remains unclear. Recently, it has also been shown that Fur, when applied topically, dilates tracheal arterioles and venules by both cyclooxygenase- and nitric oxide-independent mechanisms [3].

Previous observations have suggested that Fur inhibits leukotriene (LT) synthesis from lung fragments [4] and after allergy-induced early reaction [5]. GómEz et al. [6] have recently shown that 5-lipoxygenase selective inhibitor (e.g. zileuton) administration in patients with mild asthma attenuated PAF-induced systemic and pulmonary effects, thereby suggesting that these effects may be partially mediated by the LT pathway. Effective inhibition of PAF-induced effects by Fur might indicate that this drug, primarily, has an immediate anti-inflammatory effect, probably via LT inhibition. Alternatively, a failure by Fur to abolish PAF-induced abnormalities may indicate that the vasodilatory effects of Fur on airway vessels via enhanced abnormally increased microvascular leakage provoked by PAF, play a major role. The objective of this study was to investigate in patients with mild asthma whether Fur pretreatment could modulate the systemic, cellular, and pulmonary effects induced by PAF inhalation.

\section{Methods}

\section{Study population}

Eleven patients with mild asthma (table 1) were recruited from the Outpatient Dept, and the study was 
Table 1. - Anthropometric and baseline function data on placebo and furosemide studies

\begin{tabular}{|c|c|c|c|}
\hline & Baseline & Placebo I & Furosemide \\
\hline $\mathrm{n}$ & 11 & & \\
\hline Sex M/F & $4 / 7$ & & \\
\hline Age yrs & $21.5 \pm 0.80$ & & \\
\hline Height $\mathrm{cm}$ & $165 \pm 1.7$ & & \\
\hline Weight kg & $66.3 \pm 3.6$ & & \\
\hline FEV1 L & $3.5 \pm 0.2$ & & \\
\hline FEV1 \% pred & $95 \pm 4.2$ & & \\
\hline FEV1/FVC \% & $80 \pm 3.3$ & & \\
\hline PD20 $\mu \mathrm{mol}$ & $0.98 \pm 0.4$ & & \\
\hline Neutrophils $\times 10^{9}$ cells $\cdot \mathrm{L}^{-1}$ & & $3.1 \pm 0.4$ & $3.3 \pm 0.3$ \\
\hline$V^{\prime} \mathrm{E} \mathrm{L} \cdot \mathrm{min}^{-1}$ & & $5.1 \pm 0.3$ & $5.9 \pm 0.3$ \\
\hline$R \mathrm{rs} \mathrm{cmH}_{2} \mathrm{O} \cdot \mathrm{L}^{-1} \cdot \mathrm{s}^{-1}$ & & $3.7 \pm 0.3$ & $3.8 \pm 0.5$ \\
\hline$P a, \mathrm{O}_{2} \mathrm{mmHg}$ & & $96.7 \pm 1.8$ & $96.6 \pm 1.8$ \\
\hline$P \mathrm{a}, \mathrm{CO}_{2} \mathrm{mmHg}$ & & $38.4 \pm 0.9$ & $37.4 \pm 0.9$ \\
\hline $\mathrm{A}-\mathrm{a} \mathrm{PO}_{2} \mathrm{mmHg}$ & & $8.2 \pm 1.1$ & $9.1 \pm 1.5$ \\
\hline$V^{\prime} \mathrm{O}_{2} \mathrm{~mL} \cdot \mathrm{min}^{-1}$ & & $195 \pm 11.1$ & $214 \pm 9.8$ \\
\hline HR $\min ^{-1}$ & & $70 \pm 2.5$ & $70 \pm 2.0$ \\
\hline Ps mmHg & & $78.8 \pm 1.9$ & $80.7 \pm 1.8$ \\
\hline $\mathrm{uLTE}_{4} \mathrm{pg} \cdot \mathrm{mg}$ creatinine $^{-1}$ & & $551 \pm 203$ & $392 \pm 81$ \\
\hline
\end{tabular}

Data are presented as mean \pm SEM. M: male; F: female; FEV1: forced expiratory volume in one second; FVC: forced vital capacity; PD20: provocative dose of methacholine causing a $20 \%$ fall in FEV1; $V^{\prime} \mathrm{E}$ : minute ventilation; Rrs: respiratory system resistance; $\mathrm{Pa}, \mathrm{O}_{2}$ : oxygen tension in arterial blood; $\mathrm{Pa}_{\mathrm{a}} \mathrm{CO}_{2}$ : carbon dioxide tension in arterial blood; $\mathrm{A}-\mathrm{a}_{\mathrm{O}_{2}}$ : alveolar-arterial partial pressure of oxygen difference; $V^{\prime} \mathrm{O}_{2}$ : oxygen uptake; $\mathrm{HR}$ : heart rate; Ps: mean systemic pressure; $\mathrm{uLTE}_{4}$ : urinary leukotriene $\mathrm{E}_{4}$. Normal PD20 value $=>4.0 \mathrm{mmol} .1 \mathrm{mmHg}=0.133 \mathrm{kPa}$

approved by the Ethical Research Committee of the Hospital clínic at the Universitat de Barcelona. All subjects gave informed written consent after the purpose, risks and potential benefits of the study were explained to them.

The inclusion criteria were: no respiratory infection or exacerbation of asthma within the preceding 6 weeks; forced expiratory volume in one second (FEV1) $>70 \%$ predicted and $>1.5 \mathrm{~L}$; positive methacholine (provocative dose causing a $20 \%$ fall in FEV1 $\left.\left(\mathrm{PD}_{20}\right)<4.0 \mu \mathrm{mol}\right)$ and PAF $(20 \%$ increase of baseline respiratory system resistance $(R \mathrm{rs})$ after PAF $(18 \mu \mathrm{g}))$ bronchial challenges; maintenance therapy with aerosol short-acting $\beta_{2}$-adrenergics on demand ( 8 patients), with or without regular inhaled glucocorticosteroids ( $800 \mu \mathrm{g}$ daily) (2 patients) and/ or long acting $\beta_{2}$-adrenergics (1 patient), but no previous treatment with oral steroids; and, absence of any systemic or cardiopulmonary disease other than asthma. All subjects were nonsmokers and atopic, as judged by the presence of a positive response to skin prick tests to one or more common aeroallergens.

\section{Measurements}

Blood samples were collected anaerobically through a catheter inserted into the radial artery. Arterial partial pressure of oxygen $\left(\mathrm{PO}_{2}\right)$, partial pressure of carbon dioxide $\left(\mathrm{PCO}_{2}\right)$ and $\mathrm{pH}$ were analysed in duplicate using standard electrodes, and haemoglobin concentration was measured by a Co-oximeter (Ciba Corning 860 System; Ciba Corning Diagnostics Corporation, Meadfield, MA, USA). Both $\mathrm{O}_{2}$ uptake $\left(V^{\prime} \mathrm{O}_{2}\right)$ and $\mathrm{CO}_{2}$ production $\left(V^{\prime} \mathrm{CO}_{2}\right)$ were calculated from mixed expired $\mathrm{O}_{2}$ with a Zirconia analyser (MCG Medical Graphics Corporation, St. Paul,
$\mathrm{MN}$, USA), and $\mathrm{CO}_{2}$ concentrations by a nondispersive infrared analyser (NDIR) (Model CPX/D, MCG Medical Graphics Corporation). Both minute ventilation $\left(V^{\prime} \mathrm{E}\right)$ and respiratory rate (RR) were measured using a calibrated Wright spirometer (Respirometer MK8; BOC-Medical, Essex, UK). The alveolar-arterial $\mathrm{PO}_{2}$ gradient $\left(\mathrm{A}-\mathrm{a} \mathrm{PO}_{2}\right)$ was calculated according to the alveolar gas equation using the measured respiratory exchange ratio $(\mathrm{R})$.

Total white cell counts in arterial blood were measured with a Technicon H.1 ${ }^{\text {TM }}$ System (Technicon, Tarytown, New York, NY, USA). Patients received nebulized Fur (40 mg) (Hoechst AG, San Feliu de Llobregat, Spain) or placebo $(\mathrm{P})(\mathrm{ClNa}$ solution $0.9 \%$ adjusted to $\mathrm{pH} 9.0$ by the addition of sodium hydroxide $(\mathrm{NaOH})$ via an ultrasonic nebulizer (OMROM NE-U07; OMROM Corporation, Tokyo, Japan; volume: $4 \mathrm{~mL}$; mass median aerodynamic diameter of the particles: $1-5 \mathrm{~mm}$; output: $1 \mathrm{~mL} \cdot \mathrm{min}^{-1}$ frequency: 1-5 MHz)).

The measurement of Rrs was carried out via the forced oscillation technique and its analysis restricted to $8 \mathrm{~Hz}$ [6]. A three-lead electrocardiogram, heart rate (HR), systemic pressure $(P \mathrm{~s})$ and arterial $\mathrm{O}_{2}$ saturation were continuously recorded through a pulseoximeter (HP M1166A; HewlettPackard, Boblingen, Germany) throughout the whole study (HP 7830A Monitor and HP 7754B Recorder; Hewlett-Packard, Waltham, MA, USA). Measurements of urinary cysteinyl leukotriene $\mathrm{E}_{4}\left(\mathrm{uLTE}_{4}\right)$, were corrected for urinary creatinine and urine volume, were carried out with a validated enzyme immunoassay (EIA) $[6,7]$.

\section{Study design}

A randomized double-blind, placebo-controlled, crossover design was used. All patients were challenged on two occasions, one week apart, with inhaled PAF after the administration of either Fur or P, with patients breathing room air and seated in an armchair. All asthma medication was withheld for $48 \mathrm{~h}$ before arrival to the laboratory on the day of the study. After the establishment of adequate steady-state conditions, a set of duplicate measurements of arterial blood respiratory gases, $\mathrm{O}_{2}$ and $\mathrm{CO}_{2}$ fractions in mixed expired gases, white blood cell counts, urinary samples, ventilatory and haemodynamic parameters, and $R \mathrm{rs}$ was carried out (baseline). Maintenance of steady-state conditions after PAF challenge was demonstrated by stability $( \pm 5 \%)$ of both ventilatory and haemodynamic variables and by close agreement between duplicate measurements of mixed expired and arterial $\mathrm{O}_{2}$ and $\mathrm{CO}_{2}$ (within $\pm 5 \%$ ). These conditions were met in all patients throughout the period of study. Immediately after approximately $15 \mathrm{~min}$ of Fur or P nebulization, another set of all of the measurements except that for $\mathrm{uLTE}_{4}$, was performed and $15 \mathrm{~min}$ later, the patients were challenged with PAF $\left(\mathrm{C}_{16}\right)(1-\mathrm{O}-$ Hexedecyl-2-acetyl-sn-glycero-3-phosphocholine) $(18 \mu \mathrm{g})$ (Novabiochem AG, Laufelfingen, Switzerland). The preparation of the PAF solution and details of the PAF challenge have been previously reported in full $[6,8-10]$. Duplicate measurements were taken at 5,15 , and $45 \mathrm{~min}$ following PAF inhalation, as described previously $[6,8-$ 10]. All sets of measurements consisted of the following steps in sequence: haemodynamic and ventilatory recordings; respiratory gas and circulating white blood cells samplings and, Rrs measurements. No patient needed 
rescue medication with short-acting $\beta_{2}$-adrenergics at the end of each study period.

Urine samples for $\mathrm{ULTE}_{4}$ levels were collected at baseline (before Fur or P nebulization) and $120 \mathrm{~min}$ after PAF challenge. Because changes in urinary creatinine concentration (depend upon volume of urine) after Fur nebulization and PAF challenge may modulate the levels of $\mathrm{uLTE}_{4}$, a third bronchoprovocation test with PAF $(18 \mu \mathrm{g})$ was carried out, in 8 out of the 11 patients, at least 1 month later. All patients were pretreated with nebulized Fur (40 $\mathrm{mg}$ ) following the same protocol (see above) before PAF challenge, and volume of urine in addition to urinary creatinine and $\mathrm{LTE}_{4}$ levels were measured before and 120 min after PAF inhalation. There was no oral fluid intake during the period of study.

\section{Statistical analysis}

The results are expressed as mean \pm SEM. The effects of PAF challenge and those of pretreatment with Fur or P on the different end-point variables were assessed by a twoway repeated analysis of variance (ANOVA). This test was performed after checking for both homogeneity of variances and normal distribution of variables. When the $F$ value of the ANOVA was significant, post hoc comparisons were performed using paired Student t-test. In the third PAF study, in which patients were pretreated with Fur only, a Student t-test was used to compare $\mathrm{uLTE}_{4}$ before and after PAF inhalation. All analyses were performed with SPSS version 6.1.3 (SPSS Inc., Chicago, IL, USA). Statistical significance was set at $\mathrm{p}<0.05$.

\section{Results}

\section{Baseline data before platelet-activating factor}

In table 1, mean baseline anthropometric and functional measurements of all patients are shown. All were similar to those reported in previous investigations $[6,9,10]$ without baseline differences between Fur or vehicle study days. Except for $\mathrm{uLTE}_{4}$, which was not measured immediately after Fur or P (see above), no differences were shown between baseline and post-Fur or P measurements, before PAF inhalation, and accordingly, all comparisons after PAF challenge were performed taking into account baseline data measured before Fur or P nebulization.

\section{Effects of platelet-activating factor after placebo}

All but 3 patients noticed facial flushing, 4 coughed and 8 felt shortness of breath immediately after PAF challenge. There were no differences in the response to PAF between patients treated with or without inhaled glucocorticosteroids. Peripheral blood neutrophils fell at 5 min after PAF inhalation (from $3.09 \pm 0.4 \times 10^{9}$ cells $\cdot \mathrm{L}^{-1}$ to $2.07 \pm 0.5 \times 10^{9}$ cells $\left.\cdot \mathrm{L}^{-1} ; \mathrm{p}<0.01\right)$, followed by a rebound neutrophilia at 15 and $45 \mathrm{~min}$ (to $4.29 \pm 0.6$ and $4.52 \pm$ $0.7 \times 10^{9}$ cells $\cdot \mathrm{L}^{-1} ; \mathrm{p}<0.03$ and 0.04 , respectively; fig. 1$)$. Total Rrs increased at $5 \mathrm{~min}$ after PAF challenge (from $3.68 \pm 0.3 \mathrm{cmH}_{2} \mathrm{O} \cdot \mathrm{L}^{-1} \cdot \mathrm{s}^{-1}$ to $6.24 \pm 1.2 \mathrm{cmH}_{2} \mathrm{O} \cdot \mathrm{L}^{-1} \cdot \mathrm{s}^{-1} ; \mathrm{p}<$ 0.04). Moreover, arterial $\mathrm{PO}_{2}$ decreased and $\mathrm{A}-\mathrm{a} \mathrm{PO}_{2}$
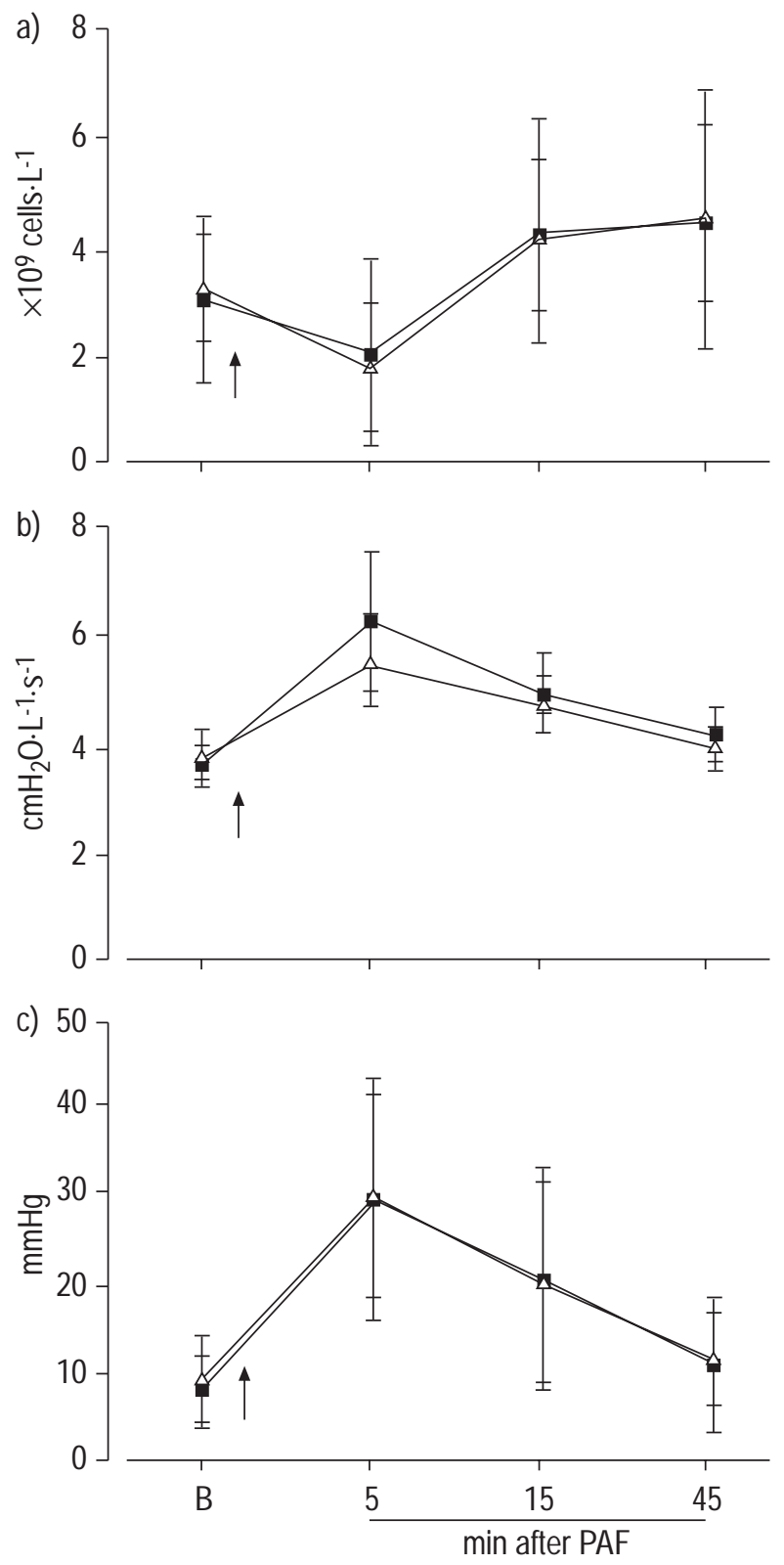

Fig. 1. - Mean ( \pm SEM) values of: a) neutrophils, b) resistance of the respiratory system, and c) alveolar-arterial partial pressure of oxygen difference, after inhaled platelet-activating factor (PAF) (arrow) in placebo

(ם) and furosemide $(\triangle)$ studies at baseline $(B)$ and at 5, 15 and $45 \mathrm{~min}$. No differences were shown in any of the variables (see text). $1 \mathrm{mmHg}=$ $0.133 \mathrm{kPa}$.

increased at $5 \mathrm{~min}$ (from $12.9 \pm 0.2 \mathrm{kPa}(96.7 \pm 1.8 \mathrm{mmHg}$ ) and $1.1 \pm 0.2 \mathrm{kPa}(8.2 \pm 1.1 \mathrm{mmHg})$ to $10.3 \pm 0.5 \mathrm{kPa}(77.7 \pm$ $3.7 \mathrm{mmHg})$ and $4.0 \pm 0.5 \mathrm{kPa}(29.7 \pm 4.0 \mathrm{mmHg})$, respectively; $\mathrm{p}<0.001$ each), probably reflecting the development of low $V^{\prime} \mathrm{A} / Q^{\prime}$ ratios $[6,8-10]$. Additionally, ventilatory and haemodynamic variables and the other gas exchange indices, including arterial $\mathrm{pH}$, did not change. Compared with Fur, all of these changes were not significantly different.

By contrast, the administration of $\mathrm{P}$ induced a marked increase of $\mathrm{uLTE}_{4}$ corrected by urinary creatinine (by $63 \%$ ) 120 min after PAF inhalation, compared with Fur pretreatment (from $551 \pm 203 \mathrm{pg} \cdot \mathrm{mg}^{-1}$ to $2,254 \pm 679 \mathrm{pg} \cdot \mathrm{mg}^{-1}$ 

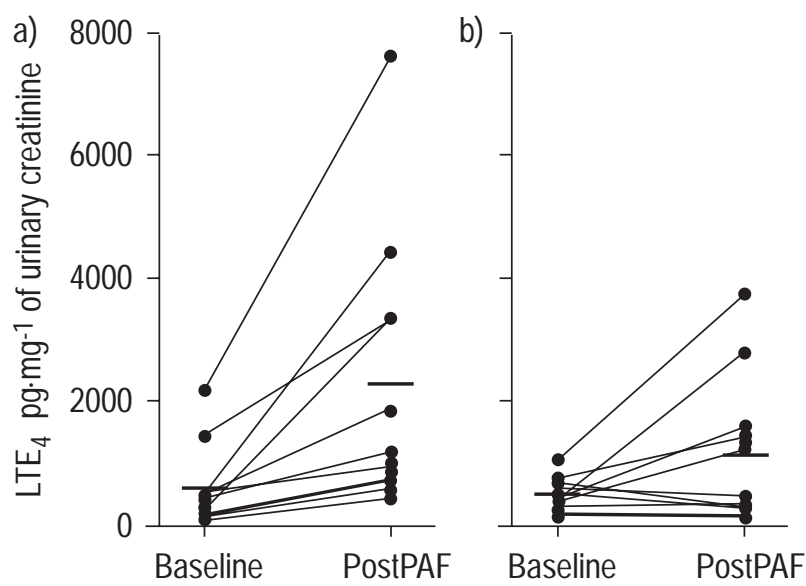

Fig. 2. - Individual and mean (solid bars) values of urinary cysteinyl leukotriene $\mathrm{E}_{4}\left(\mathrm{uLTE}_{4}\right)$ at baseline $(\mathrm{B})$ and $120 \mathrm{~min}$ after plateletactivating factor (PAF) inhalation pretreated with a) placebo of $b$ ) furosemide. The uLTE $_{4}$ levels were markedly reduced after PAF challenge when patients were pretreated with furosemide $(\mathrm{p}<0.04)$.

(an increase of $474 \pm 129 \%$ ) and from $392 \pm 81 \mathrm{pg} \cdot \mathrm{mg}^{-1}$ to $1,017 \pm 366 \mathrm{pg} \cdot \mathrm{mg}^{-1}$ (an increase of $148 \pm 85 \%$ ), respectively; p<0.04) (fig. 2).

\section{Effects of platelet-activating factor after furosemide}

As compared with vehicle, pretreatment with Fur did not abolish PAF-induced systemic effects: six patients noticed facial flushing, three coughed, and seven felt shortness of breath. Similarly, PAF-induced responses on cellular and lung function abnormalities were not attenuated (fig. 1), and no significant changes in $\mathrm{uLTE}_{4}$ levels were observed (see above) (fig. 2). Interestingly enough, $\mathrm{uLTE}_{4}$ levels were not significantly increased after PAF when corrected either by urinary creatinine concentration (from $949 \pm 135$ $\mathrm{pg} \cdot \mathrm{mg}^{-1}$ to $1,547 \pm 393 \mathrm{pg} \cdot \mathrm{mg}^{-1}$ an increase of $63 \pm 31 \%$; not significant) or urinary volume (from $97,004 \pm 13,972$ $\mathrm{pg} \cdot \mathrm{mL}^{-1}$ to $160,503 \pm 59,676 \mathrm{pg} \cdot \mathrm{mL}^{-1}$ an increase of $61 \pm$ $44 \% ; \mathrm{p}<0.3)$ in the third PAF challenge carried out 1 month later.

\section{Discussion}

The novel finding of the present study is that previous nebulization of $40 \mathrm{mg}$ of Fur (a dose similar to that used in previous studies [11]) does not modify either the systemic or the pulmonary responses provoked by PAF inhalation in patients with mild asthma $[6,9,10]$. When PAF was given after Fur, patients exhibited systemic effects (feeling of warmth, cough, and/or dyspnoea), a fall in peripheral blood neutrophils followed by an intense rebound kinetic effect, bronchoconstriction (increased Rrs), and hypoxaemia and/or increased $\mathrm{A}-\mathrm{a} P \mathrm{O}_{2}$, provoked by $V^{\prime} \mathrm{A} /$ $Q^{\prime}$ imbalance most likely characterized by the development of areas with low $V^{\prime} \mathrm{A} / Q^{\prime}$ ratios $[1,6,9,10]$. By contrast, Fur pretreatment was successful in inhibiting the increased urinary excretion of leukotriene (LT)E $\mathrm{E}_{4}$, the stable whole body metabolite of LT, after PAF challenge.

Fur has been found to be protective against bronchoconstriction induced by several types of bronchial chal- lenges in patients with asthma, especially those which act through indirect mechanisms when the release of paracrine bronchoconstrictor mediators is implicated [2]. In this sense, it has been suggested that Fur may have a similar profile of action to disodium cromoglycate [12]. However, no protection was observed against direct bronchoconstrictive agents, such as methacholine or histamine, suggesting therefore that Fur may not have a direct effect on airway smooth muscle $[2,13]$. There are studies that demonstrate that PAF induces the release of certain cytokines from cells. such as interleukin (IL)-4, IL-6, IL8 , and tumour necrosis factor-alpha (TNF- $\alpha)$ [14]. While the authors agree that it is plausible that these cytokines may mediate some of the effects that have been observed with PAF inhalation in asthmatics i.e. the neutropenia through the secondary release of IL- 8 from bronchial epithelial cells [14], they suggest that it is unlikely that Fur may be acting by inhibiting such release. Indeed, it has been found that Fur did not alter PAF-induced neutrophil kinetic abnormalities. Similarly. the authors are not aware of any data implicating a direct effect of Fur in inhibiting cytokine release from inflammatory cells in vivo. In fact, its precise mechanism has not yet been elucidated although diverse hypotheses have been proposed [11]. Moreover, the authors have shown a lack of bronchial response to solutions of $\mathrm{CINa}$ such that vehicle inhalation cannot modulate pulmonary function [15].

MCFADDEN et al. [16] showed that, in exercise-induced asthma, airway obstruction is related to the thermal gradient that develops between the airway cooling of hyperpnoea and the airway rewarming. When this gradient is lessened, the severity of the airway obstruction response is reduced. They also demonstrated that changes in airway blood flow significantly alter the gradient for intrathoracic heat exchange. GILBERT et al. [17] observed that inhaled Fur reduced the thermal gradient for rewarming of the airways after hyperpnoea and proposed that the protective action of this agent was due to the increased blood flow to the airways. CoRBOz et al. [3] confirmed that Fur, when applied topically in a rat model, dilates tracheal arterioles and venules by cyclo-oxygenase- and nitric oxide-independent mechanisms. In addition, Fur is known to be an effective vasodilator of the pulmonary circulation [12].

Based on previous work, in both healthy individuals $[8$, $18,19]$ and in patients with mild asthma $[6,9,10]$, the authors postulate that PAF-induced pulmonary gas exchange abnormalities and increases of $R$ rs are related to narrowing of airway lumenal calibre secondary to abnormally increased microvascular leakage rather than to a primary constrictor effect on airway smooth muscle by itself. Mediators that increase abnormal vascular permeability on bronchial circulation operate directly on the post-capillary venular wall endothelium, possibly by altering normal cell-to-cell contact and inducing the presence of intercellular gaps $[1,20]$. The mechanism of these gaps has been accepted as a contractile phenomenon provoking wide clefts intercellularly. As a result, nonsieved plasma and cells escape via these venular holes into the interstitial airway wall, possibly under the influence of the hydrostatic pressure gradient $[1,20]$. Both the postcapillary venular endothelium and the mucosal epithelium seem to harbour anti-leakage mediating $\beta_{2}$ receptors. 
$\beta_{2}$-receptor agonists were among the first drugs that were demonstrated to exhibit anti-oedema effects in a variety of systemic vascular beds [20]. In this regard, it has been shown that inhaled salbutamol $(300 \mu \mathrm{g})$, but not ipratropium bromide $(80 \mu \mathrm{g})$, was efficacious in completely antagonizing PAF-inducing effects in a laboratory-induced model developed in control subjects [18] and in patients with asthma [10]. Conceivably, the vasodilatory effect on bronchial circulation provoked by Fur [3] may interact with the constrictive effects of PAF on endothelial cells, hence ultimately modulating the subsequent lung function abnormalities on both airway tone and pulmonary gas exchange induced by bronchoconstriction and abnormally increased airway permeability. Moreover, this vasodilatory effect of Fur can also be active in the pulmonary circulation [12], thus modulating the tone of the vessels and consequently not affecting the transitory sequestration of neutrophils provoked by PAF. Fur has been shown to be active as a vasodilator at concentrations of $10^{-4} \mathrm{M}$ [3], but this concentration could have been achieved in the airways submucosa since a concentration of $3.0 \times 10^{-2} \mathrm{M}$ was aerosolized and since even allowing for a dilution factor of 100 for this diffusible molecule, such active concentrations of Fur would be achieved at the assumed sites of action. However, direct measurements are not available and therefore the hypothesis of the airway vascular mechanisms of action for Fur relies on the likelihood of achieving these concentrations.

Akin to former studies [4, 5], $\mathrm{uLTE}_{4}$ was observed not to increase significantly after PAF when Fur was preadministered. Leukotrienes may be involved as secondary mediators in the production of the systemic and pulmonary effects caused by PAF in asthmatic patients. It has been recently proven that PAF can increase the subsequent release of chemotactic mediator $\mathrm{LTB}_{4}$, thereby suggesting that it may prime the constitutive cells of the lung to augment inflammatory effects relevant to the pathogenesis of asthma [21]. The administration of PAF in humans is associated with an increase in $\mathrm{ULTE}_{4}$ and these augmented levels reflect an integrated form of endogenous whole body $\mathrm{LTC}_{4}$ and $\mathrm{LTD}_{4}$ release during a specific period of time [22]. The author's group recently observed that oral pretreatment with zileuton $(600 \mathrm{mg})$, a selective 5-lipoxygenase inhibitor, partially abolished PAF-induced pulmonary effects in patients with mild asthma by a slightly lower order of magnitude than in the current study [6], therefore suggesting that LT can mediate the latter effects. Although in the current study $\mathrm{LTE}_{4}$ urinary excretion was inhibited, there was no prevention of PAF-induced bronchoconstriction. This could be due to the possibility that inhibition of the 5-lipoxygenase enzyme needs to be complete before functional abolition of bronchoconstriction is observed. A reduction by about half $\mathrm{LTE}_{4}$ urinary excretion by zileuton in a previous study was not associated with any modulation of the allergen-induced late phase response [23].

In summary, one plausible explanation for the lack of action of furosemide on platelet-activating factor-induced systemic and pulmonary effects in this study, is that platelet-activating factor can be an inflammatory mediator that may exert its effects through different pathways, involving not only the release of leukotriene but also that of other putative inflammatory mediators. In this sense, the vasodilatory activity of furosemide could enhance vascular leakage thus facilitating both the systemic and pulmonary effects induced by platelet-activating factor inhalation, a response that cannot be offset even with the partial inhibition of leukotriene. This is reflected by reducing the increased urinary excretion of its stable metabolite, urinary cysteinyl leukotriene $\mathrm{E}_{4}$.

\begin{abstract}
Acknowledgements. The authors are grateful to G. Gómez, from the Departament de Bioanalítica Médica, Consell Superior d'Investigacions Científiques (CSIC), for the studies on urinary cysteinyl leukotriene $\mathrm{E}_{4}$; and, to J. Cardús, F. Burgos, C. Gistau, T. Lecha, M. Simó, C. Argaña, and M. Carrión for their outstanding technical support.
\end{abstract}

\section{References}

1. Rodriguez-Roisin R. Acute severe asthma: pathophysiology and pathobiology of gas exchange abnormalities. Eur Respir J 1997; 10: 1359-1371.

2. Chung KF, Barnes PJ. Loop diuretics and asthma. Pulm Pharmacol 1992; 5: 1-7.

3. Corboz MR, Ballard ST, Inglis ST, Taylor AE. Dilatory effect of furosemide on rat tracheal arterioles and venules. Am J Respir Crit Care Med 1997; 156: 478-483.

4. Anderson SD, Wei He BS. Inhibition by furosemide of inflammatory mediators from lung fragments (Letter to Editor). N Engl J Med 1990; 324: 131.

5. Bianco S, Sala A, Robuschi M, Luppi S, Sestini P, Folco GC. Effect of inhaled furosemide on urinary leukotriene $\mathrm{E}_{4}$ in allergen-induced early asthmatic reactions (Abstract). Pharmacol Research 1992; 26: 36.

6. Gómez FP, Iglesia R, Roca J, Barbera JA, Chung KF, Rodriguez-Roisin R. The effect of 5-lipoxygenase inhibition by zileuton on platelet-activating factor-induced pulmonary abnormalities in mild asthma. Am J Respir Crit Care Med 1998; 157: 1559-1564.

7. Kumlin M. Measurements of leukotrienes in the urine: strategies and applications. Allergy 1997; 52: 124-135.

8. Rodriguez-Roisin R, Félez MA, Chung KF, et al. Plateletactivating factor causes ventilation-perfusion mismatch in humans. J Clin Invest 1994; 93: 188-194.

9. Félez MA, Roca J, Barbera JA, et al. Inhaled plateletactivating factor worsens gas exchange in mild asthma. Am J Respir Crit Care Med 1994; 150: 369-373.

10. Díaz O, Barbera JA, Marrades R, Chung KF, Roca J, Rodriguez-Roisin R. Inhibition of PAF-induced gas exchange defects by beta-adrenergic agonists in mild asthma is not due to bronchodilation. Am J Respir Crit Care Med 1997; 156: 17-22.

11. Bianco S, Pieroni MG, Refini RM, Sestini P, Robuschi M, Vaghi A. Protective effect of inhaled loop diuretics on experimentally induced bronchoconstriction. In: Spector SL, editors. Provocation testing in clinical practice. New York, Marcel Dekker Inc., 1995; 411-423.

12. Lockhart A, Slutsky AS. Furosemide and loop diuretics in human asthma. Chest 1994; 106: 244-249.

13. O'Connor BJ, Chung KF, Chen-Worsdell YM, Fuller RW, Barnes PJ. Effect of inhaled furosemide and bumetanide on adenosine $5^{\prime}$-monophosphate- and sodium metabisulphite-induced bronchoconstriction in asthmatic subjects. Am Rev Respir Dis 1991; 143: 1329-1333.

14. Matsumoto K, Hashimoto S, Gon Y, Nakayam T, Horie T. Proinflammatory cytokine-induced and chemical media- 
tor-induced IL- 8 expression in human bronchial epithelial cells through p38 mitogen-activated protein kinase-dependent pathway. J Allergy Clin Immunol 1998; 101: 825831.

15. Marrades RM, Roca J, Barberà JA, de Jover LI, MacNee W, Rodriguez-Roisin R. Nebulized glutathione induces bronchoprovocation in patients with mild asthma. $A m J$ Respir Crit Care Med 1997; 156: 425-430.

16. McFadden ER, Lenner KAM, Strohl KP. Postexertional airway rewarming and thermally induced asthma. J Clin Invest 1986; 78: 18-25.

17. Gilbert IA, Lenner A, Nelson JOA, Wolin AD, Fouke JM. Inhaled furosemide attenuates hyperpnea-induced obstruction and intra-airway thermal gradients. $J$ Appl Physiol 1994; 76: 409-415.

18. Roca J, Félez MA, Chung KF, et al. Salbutamol inhibits pulmonary effects of platelet-activating factor in man. $\mathrm{Am}$ J Respir Crit Care Med 1995; 151: 1740-1744.

19. Masclans JR, Barberà JA, MacNee W, et al. Salbutamol reduces pulmonary neutrophil sequestration of plateletactivating factor in humans. Am J Respir Crit Care Med 1996; 154: 529-532.

20. Persson CGA. Tracheobronchial microcirculation in asthma. In: Kaliner JA, Barnes PJ, Persson C, eds. Asthma. Its pathology and treatment. New York, Marcel Dekker Inc., 1991; 209-229.

21. Shindo K, Koide K, Fukumura M. Platelet-activating factor increases leukotriene $\mathrm{B}_{4}$ release in stimulated alveolar macrophages from asthmatic patients. Eur Respir $J$ 1998; 11: 1098-1104.

22. Taylor IK, Ward PS, Taylor GW, Dollery CT, Fuller RW. Inhaled PAF stimulates leukotriene and thromboxane $\mathrm{A}_{2}$ production in humans. J Appl Physiol 1991; 71: 13961402.

23. Hui KP, Taylor IK, Taylor GW, et al. Effect of a 5-lipoxygenase inhibitor on leukotriene generation and airway responses after allergen in asthmatic patients. Thorax 1991; 46: 184-189. 